\title{
ZEMLJIŠNI I BILJNO PROIZVODNI UVJETI ZA NATAPANJE POLJOPRIVREDNIH KULTURA U KRAPINSKO ZAGORSKOJ ŽUPANIJI $^{1}$
}

\author{
LAND AND PLANT PRODUCTION CONDITIONS FOR THE \\ IRRIGATION OF AGRICULTURAL CROPS IN \\ KRAPINA ZAGORJE COUNTY
}

\section{Ž. Vidaček, Dragica Tresk Penezić, M. Plantak}

\section{SAŽETAK}

U krapinsko zagorskom kraju sve su češće pojave manjka oborina i vode u tlu za normalan rast i razvoj usjeva. U cilju primjene natapanja i intenzivne poljoprivredne proizvodnje ${ }^{2}$, u članku analiziramo u prvom redu sadašnju i potencijalnu pogodnost poljoprivrednog zemljišta za natapanje do 500 m.n.m., nagiba terena $0-16 \%$, ukupno neto površine 50.075 ha, zatim stanje posjedapoljoprivrednih gospodarstava i mogućnosti izbora kultura. Poljoprivredne površine županije obuhvaćaju oko $58 \%$ teritorija. Obrađuje se oko $50 \%$. U privatnom vlasništvu je oko 99\%. Osnovno obilježje poljoprivrednih gospodarstava je usitnjenost i rascjepkanost posjeda. Od zasijanih kultura prevladavaju žitarice $(71 \%)$, krmno bilje $(16,8 \%)$, krumpir $(8,2 \%)$, povrće $(4 \%)$, dok je pod ugarom i neobrađenih oranica i vrtova oko 3\% poljoprivredne površine. U 2016. godini je natapano 19,35 hektara ratarskih i povrtnih kultura i voća na 51 ARKOD parceli i u 29 gospodarstava.

Prema utvrđenom stupnju pogodnosti tla za natapanje i nagibu terena, preporučamo po načelu intenzivne poljoprivrede agro ili/i hidrotehničke mjere uređenja poljoprivrednog zemljišta, okrupnjavanje posjeda, tržišno održivi izbor poljoprivrednih kultura i odgovarajuće načine gospodarenja-korištenja poljoprivrednog zemljišta s natapanjem. ${ }^{3}$

Ključne riječi: pogodnost tla/zemljišta za natapanje, biljna proizvodnja, agro i hidromelioracije, komasacija, arondacija

\footnotetext{
${ }^{1}$ Globalna primiena održive proizvodnje hrane zahtijevat će velike napretke u učinkovitosti korištenja resursa i zaštiti okoliša, FAO

${ }^{2}$ Intenzivna poljoprivreda se temelji na kapitalnim investicijama, novim tehnologijama, dohodovnim kulturama, intenziviranom plodoredu i natapanju u odnosu na tradicionalnu poljoprivredu, koja u najvećoj mjeri ovisi o vremenskim uvjetima i tradicionalnoj tehnologiji.

${ }^{3}$ Natapanje kao hidrotehnički i/ili agrotehnički zahvat u biljnoj proizvodnji, povoljno utječe na promjene mikroklime zraka $\mathrm{i}$ tla, te na procese transformacije i premještanja organskih $\mathrm{i}$ mineralnih tvari u sustavu tlo-biljka.
} 
Ž. Vidaček i sur.: Zemljišni i biljno proizvodni uvjeti za natapanje poljoprivrednih kultura u Krapinsko zagorskoj županiji

\begin{abstract}
In the Krapina Zagorje region, there are more frequent shortagees of precipitation and water in the soil for normal growth and development of crops. In order to apply grease and intensive agricultural production, the article analyzes in the first place the current and potential advantage of agricultural land for tillage up to 500 m.n.m., sloping ground $0-16 \%$, total net area $50.075 \mathrm{ha}$, then the state of agricultural holdings and the possibility of choosing cultures. The county's agricultural area covers about $58 \%$ of the territory. Approximately $50 \%$ is processed. Private ownership is about $99 \%$. The basic feature of agricultural holdings is the fragmentation. Of the sown crops, cereals $(71 \%)$, fodder crops $(16.8 \%)$, potatoes $(8.2 \%)$, vegetables $(4 \%)$ prevail over grazing and unprocessed fields and gardens, accounting for about $3 \%$ of the agricultural area. In year 2016, in total 19.35 hectares of agricultural and vegetable crops and fruit were planted on 51 ARKOD parcels and 29 farms. According to the established degree of suitability of soil for irrigatin and tilting the terrain, we recommend on the principle of intensive agriculture agro and hydro-technical measures for the amelioration of agricultural land, land consolidation, a viable selection of agricultural crops and appropriate ways of managing and using agricultural land with irrigation.
\end{abstract}

Key words: Soil and Land Suitability, Plant Production, Agro and Hydromelioration, Comasation, Arondation

\title{
UVOD
}

Krapinsko-zagorska županija (KZŽ), je smještena u sjeverozapadnom dijelu Republike Hrvatske. Obuhvaća zapadni dio središnje Hrvatske, pripadajući području zagrebačke makroregije. Geografski se podudara s prirodnom regijom Donje Zagorje. U ukupnoj površini Hrvatske zauzima 2,17\%. Ističe se kontinentalno-humidni tip klime s umjereno toplim ljetom i dosta kišovitom i hladnom zimom.. Česte su obilne kiše i poplave, klizišta i štete na usjevima zbog poplava ili manjka oborina. U sušnim ljetnim mjesecima, posebno u razdoblju srpanj - kolovoz ugrožena je kvaliteta i visina prinosa uzgajanih poljoprivrednih kultura na otvorenom. Najviše štete na otvorenom bude na ratarskim i krmnim usjevima, te na povrću i cvijeću. Za vrijeme suša dužeg trajanja stradavaju i drvenaste kulture. 
Ž. Vidaček i sur.: Zemljišni i biljno proizvodni uvjeti za natapanje poljoprivrednih kultura u Krapinsko zagorskoj županiji

Zbog ograničenih mogućnosti povećanja poljoprivrednih površina, u županiji je potrebno racionalnije korištenje poljoprivrednog zemljišta $\mathrm{s}$ natapanjem. Dosadašnja iskustva potvrđuju, da je natapanje dohodovnih kultura na melioriranom zemljištu isplativa agrotehnička i hidrotehnička mjera za dobivanje stabilnih prinosa, veću dobit, te dobru kvalitetu i konkurentnost poljoprivrednih proizvoda na slobodnom tržištu ${ }^{4}$.

U članku razmatramo problematiku natapanja s aspekta Nacionalnog projekta natapanja, Programa ruralnog razvoja RH, Strategije razvoja županije, stanja poljoprivrede, odvodnje i natapanja u županiji, sadašnje i potencijalne pogodnosit poljoprivrednog zemljišta za natapanje, stanja posjedapoljoprivrednih gospodarstava, izbora kultura za natapanje, održivog korištenja poljoprivrednog zemljišta, primjene agromelioracija i hidromelioracija, stabilnih prinosa i proizvodnje tržišno konkurentnih kultura s natapanjem. Navedene preporuke prilog su vrlo kompleksnom planiranju, projektiranju, izvođenju i funkcioniranju sustava za natapanje u domeni zemljišnih i biljno proizvodnih uvjeta.

\section{NACIONALNI PROJEKT NATAPANJA}

Još početkom 2004. godine Vlada Republike Hrvatske pokrenula je aktivnosti izrade Nacionalnog projekta natapanja i gospodarenja poljoprivrednim zemljištem i vodama u Republici Hrvatskoj, (Romić, D. i Marušić, J., 2005.5). U analizi moguće realizacije projekta, navodi se problematika potrebe poljoprivrednih kultura za vodom, zemljišni resursi u smislu pogodnosti tala za natapanje i rajonizacija površina prema pogodnosti za natapanje po županijama, te raspored vodnih resursa prema vrsti zahvata iz površinskih vodotoka, akumulacija, retencija i podzemnih voda.

Realizacija projekta je započela izradom i usvajanjem županijskih planova natapanja, te izradom projektne dokumentacije za izgradnju objekata i sustava natapanja kao sastavnog dijela programa optimalnog gospodarenja tlom i vodom za potrebe proizvodnje hrane. U rangiranju područja prema prioritetima za natapanje na nacionalnoj razini, primijenjeno je više kriterija. Kao najvažniji kriteriji za natapanje, uzeti su prirodni potencijali tla i vode, deficit vode $\mathrm{i}$ socioekonomski čimbenici.

\footnotetext{
${ }^{4} \mathrm{Na}$ slobodnom tržištu, cijenu proizvoda određuju ponuda i potražnja. a stabilnost količine i kvaliteta plasiranog proizvoda su šanse za povoljniju cijenu.

${ }^{5} \mathrm{U}$ Nacionalnom projektu natapanja Ž. Vidaček je suradnik i autor u poglavlju Pogodnost tala za natapanje-Kriteriji i rezultati procjene
} 
Ž. Vidaček i sur.: Zemljišni i biljno proizvodni uvjeti za natapanje poljoprivrednih kultura u Krapinsko zagorskoj županiji

2. PROGRAM RURALNOG RAZVOJA RH ZA RAZDOBLJE 2014. - 2020. MJERA 4. 1. ULAGANJA U FIZIČKU IMOVINU.

U sklopu ove mjere prihvatljiva su brojna ulaganja koja su hrvatskim poljoprivrednicima postala dostupna već za trajanja pretpristupnog programa IPARD. Sada je opseg ulaganja daleko širi. Mjera omogućava brojna ulaganja u primarnu poljoprivredu i preradu poljoprivrednih proizvoda, kao i u djelatnosti usmjerene ka natapanju poljoprivrednih površina i očuvanja krajobraznih vrijednosti.

Podmjera 4.1. i potpora za ulaganja u poljoprivredna gospodarstva, između ostalog ukljućuje ulaganje u izgradnju $\mathrm{i} / \mathrm{ili}$ opremanje novih sustava za natapanje na poljoprivrednom gospodarstvu, te poboljšanje postojećih sustava/opreme za natapanje te kupnju zemljišta i objekata radi realizacije projekta.

\section{STRATEGIJA RAZVOJA ŽUPANIJE 2016. - 2020.}

Na poljoprivredu županije posebno utječu zemljišni uvjeti, razmještenost stanovnika i tradicionalni način življenja na manjim posjedima.

Prioriteti razvoja poljoprivredne proizvodnje su: izgradnja tržišne infrastrukture (prerada, skladištenje, trženje), poticanje osnivanja zadruga i drugih oblika udruživanja proizvođača, korištenje tradicije u razvoju proizvoda $\mathrm{s}$ višom dodanom vrijednosti: brendiranje, regionalne robne marke, zaštita izvornosti, razvoj i povećanje proizvodne učinkovitosti voćarstva, vinogradarstva, povrtlarstva i cvjećarstva, razvoj i povećanje učinkovitosti proizvodnje mlijeka i mesa, kao i promocija ekološke poljoprivredne proizvodnje.

U sklopu mjera razvoja poljoprivredne proizvodnje Krapinsko-zagorske županije za 2018. godinu proveden je natječaj za potporu za povećanje poljoprivredne proizvodnje u kojem je jedna od prihvatljivih aktivnosti bila bušenje bunara za navodnjavanje i kupnja opreme za natapanje višegodišnjih nasada. 
Ž. Vidaček i sur.: Zemljišni i biljno proizvodni uvjeti za natapanje poljoprivrednih kultura u Krapinsko zagorskoj županiji

\section{STANJE POLJOPRIVREDE, ODVODNJE I NATAPANJA U ŽUPANIJI}

\subsection{Stanje poljoprivrede}

Poljoprivredne površine obuhvaćaju 57,7\%, a od toga su obradive površine $50,4 \%$. Jedno od osnovnih obilježja poljoprivrednih gospodarstava je usitnjenost posjeda i njihova rascjepkanost. Prosječna veličina posjeda iznosi 2,16 ha. Ima posjeda veličine do 1 ha površine $27,8 \%$, ima $1-3$ ha $50,9 \%$, ima 5-10 ha svega 5,2\%, a iznad 10 ha $0,3 \%$. Ukupno ima 78.455 parcela i 8.568 gospodarstava. U prosjeku svako gospodarstvo raspolaže s 9 parcela prosječne veličine 0,25 ha. Poslovni subjekti imaju zanemarivu ulogu u poljoprivrednoj proizvodnji.

Od zasijanih kultura prevladavaju žitarice (71\%), krmno bilje (16,8\%) krumpir $(8,2 \%)$, povrće $(4 \%)$, dok je pod ugarom i neobrađenih oranica i vrtova oko $3 \%$ od ukupne poljoprivredne površine. Prema podacima Agencije za plaćanja u poljoprivredi, ribarstvu i ruralnom razvoju na području Krapinsko - zagorske županije s 31.12.2017 godine upisano je 8.398 OPG-a. Dobna struktura nositelja OPG-ova s dodatnim stimuliranjem kroz izravna plaćanja, bilježi blago povećanje u skupini do 41 godinu starosti, dok 36\% gospodarstava $\mathrm{s}$ nositeljem starijim od 65 godina, pokazuje da su nositelji OPG-a pretežno osobe starije životne dobi. Obiteljska poljoprivredna gospodarstva $\mathrm{s}$ nositeljem i jednim članom čine $78 \%$ od ukupnog broja gospodarstava.

\subsection{Odvodnja, natapanje i korištenje vode u skladu sa zakonom}

\subsubsection{Odvodnja}

U nizinskom dijelu sliva rijeka Krapine i Sutle izvršena je komasacija. U slivu rijeke Sutle meliorirano je Kumrovečko polje od Razvora na sjeveru do Zelenjaka na jugoistoku u površini od 215 ha. U slivu rijeke Krapine meliorirane su površine: Jakovlje 705 ha, Trgovišće 172 ha, Gubaševo 330 ha, Zabok 804 ha, Začretje 688 ha, Bedekovčina 1204 ha, Mače 288 ha, Zlatar Bistrica 783 ha, Konjščina 437 ha i Tuhelj 381 ha. Ukupno je to 5.792 ha. Za sliv rijeka Krapine i Sutle nije izrađen program kojim bi se obuhvatili i radovi natapanja poljoprivrednih površina. Predviđena je izgradnja 36 retencija. ${ }^{6}$

${ }^{6}$ Iz retencije se voda ispušta nekontrolirano, za razliku od akumulacije gdje je to ispuštanje kontrolirano 
Ž. Vidaček i sur.: Zemljišni i biljno proizvodni uvjeti za natapanje poljoprivrednih kultura u Krapinsko zagorskoj županiji

Do sada izvedena kanalska mreža u županiji ima jedinu funkciju odvodnje površinskih voda. U 2008. godini ukupna dužina kanala je bila $318 \mathrm{~km}$ od čega je dovedeno u funkcionalno stanje 37,33 km. Kako u cijeloj Hrvatskoj tako i u županiji, kanali se ne održavaju redovito, posebno kanali III. i IV. reda. Uz navedeno, treba upozoriti i na propuste, koji se događaju nakon čišćenja vodotoka i pri ravnanju deponija. Loše niveliran deponij onemogućuje otjecanje površinske vode $s$ poljoprivrednih površina, pa na poplavljenim površinama najčešće stradavaju usjevi.

Radovi na melioriranju poljoprivrednih površina u dolinama pritoka Krapine nisu nastavljeni, a i izgrađeni melioracijski sustavi nisu najbolje održavani.

\subsubsection{Natapanje}

Na području županije nema većih uređenih površina s natapanjem. Prema podacima Državnog zavoda za statistiku na temelju provedenog Popisa poljoprivrede 2003. godine, evidentirano je tek 7,39 ha natapanih površina kod 25 gospodarstava i 2 poslovna subjekta. Vodu za natapanje iz vodovoda koristi 12 gospodarstava i poslovna subjekta, iz podzemlja 6 gospodarstava i 2 poslovna subjekta. Površinsku vodu na posjedu koristi 6 gospodarstava i samo 1 poslovni subjekt. Površinsku vodu izvan posjeda koristi 4 gospodarstava. U nekim slučajevima isti korisnik je koristio više izvora vode.

$\mathrm{Na}$ temelju podataka Agencije za plaćanja u poljoprivredi, ribarstvu i ruralnom razvoju o natapanju u županiji na dan 25.04.2016. vidljivo je povećanje natapanih površina u odnosu na Popis poljoprivrede iz 2003. godine. Ukupno se natapa 19,35 ha voćarskih i povrtlarskih kultura na 29 poljoprivrednih gospodarstava. Iz vodotoka se natapa 14 ARKOD parcela ukupne površine 6,53 ha, iz zdenaca 13 parcela površine 7,84 ha, iz javnog vodoopskrbnog sustava 15 parcela 2,61 ha i iz cisterni 9 parcela 2,37 hektara. Natapanje prskalicama se koriste na 5 parcela 1,01 ha, mini raspršivačima na 4 parcele 2,19 ha i kap po kap 40 parcela 15,57 hektara.

Spremnost za ulaganja u opremu za natapanje pokazala su i dalje pokazuju tržišna gospodarstva koja se bave dohodovnim kulturama i mogu koristiti neki od izvora vode za natapanje. Proizvođači cvijeća natapaju svoju proizvodnju na otvorenom i u zatvorenim prostorima Glavnina cvjećarske proizvodnje odvija se $\mathrm{u}$ zatvorenim prostorima. 
Ž. Vidaček i sur.: Zemljišni i biljno proizvodni uvjeti za natapanje poljoprivrednih kultura u Krapinsko zagorskoj županiji

Prema dostupnim podacima na stranici www.apprrr.hr u 2018. godini 19 gospodarstava je kroz agronet zatražilo izravna plaćanja za proizvodnju cvijeća na 5,82 ha. Značajnije površine pod cvijećem nalaze se u općinama Gornja Stubica i Marija Bistrica.

Gospodarstva $s$ tržišnom proizvodnjom voća ulažu u navodnjavanje svojih voćnjaka kako bi postigli dobar urod i tržnu kvalitetu voća. Natapaju se sljedeće voćne vrste: jagoda, aronija, kupina, malina, jabuka i kruška.

Proizvodnja povrća odvija se dijelom u zatvorenim prostorima-staklenicima, plastenicima i plastičnim tunelima, te na oraničnim površinama. Podaci Agencije za plaćanja u poljoprivredi, ribarstvu i ruralnom razvoju za 2017. godinu iz arkod baze govore o 12,53 ha staklenika i plastenika na 156 arkod parcela. Značajnije površine nalaze se u općinama Krapinske Toplice i Marija Bistrica. Sva proizvodnja povrća u zatvorenim prostorima obavezno se natapa sustavom kapanja. Dio površina s povrćem na oranicama natapa se kapanjem ili kišenjem. U zatvorenim prostorima se uzgajaju rajčica, paprika, krastavci, dok se vani uzgajaju paprika, feferoni, krastavci, rajčica vrlo malo, patliđan, razne tikvenjače, grah, cikla, luk, češnjak, salata i batat. Od nabrojenog povrća na oranicama se natapaju grah, cikla, luk i češnjak jer njihove kritične faze razvoja rjeđe dolaze u sušnom razdoblju. Mali ekstenzivni voćnjaci na okućnicama uglavnom se ne natapaju osim u periodima dužeg izostanka oborina.

\subsubsection{Korištenje vode za natapanje u skladu sa zakonom}

Prema uvjetima višestruke sukladnosti ${ }^{7}$ u koju spadaju dobri poljoprivredni i okolišni uvjet ${ }^{8}$ i korisnici vode za natapanje moraju posjedovati dozvolu za korištenje vode za natapanje poljoprivrednih površina u vidu vodopravne dozvole ili koncesije za gospodarsko korištenje voda.

Izuzetak predstavlja slučaj slobodnog korištenja voda u smislu korištenja oborinskih voda za natapanje, koje se skupljaju na zemljištu vlasnika odnosno ovlaštenika drugog stvarnog prava na zemljištu. Vodopravnu dozvolu je ishodilo 12 korisnika za natapanje 7,68 ha. Voda se koristi za natapanje povrtnih kultura, jagoda i drugih već prije spomenutih vrsta voćaka ${ }^{9}$.

\footnotetext{
${ }^{7}$ Višestruku sukladnost čine obvezni postupci kojih se moraju pridržavati poljoprivredna gospodarstva u obavljanju poljoprivredne aktivnosti, a vezani su uz zaštitu okoliša, zdravlje ljudi, životinja i bilja, te dobrobit životinja i dobre poljoprivredne i okolišne uvjete.

${ }^{8}$ Dobri poljoprivredni i okolišni uvjeti, dio su višestruke sukladnosti tj. minimalni uvjeti upravljanja na poljoprivrednim gospodarstvima, kojih se moraju pridržavati poljoprivredna gospodarstva u obavljanju poljoprivredne djelatnosti

${ }^{9}$ Podaci iz arhiva Hrvatskih voda ustupljeni na korištenje 27.04.2016.
} 
Ž. Vidaček i sur.: Zemljišni i biljno proizvodni uvjeti za natapanje poljoprivrednih kultura u Krapinsko zagorskoj županiji

\section{PEDOLOŠKI UVJETI I POGODNOST JEDINICA TALA POLJOPRIVREDNOG ZEMLJIŠTA ZA NATAPANJE}

\subsection{Pedološki uvjeti}

Poljoprivredna tla $\mathrm{u}$ županiji nastala su i razvila su se u vrlo složenim geološko-litološkim, klimatskim, hidrološkim, vegetacijskim i topografskim uvjetima. Na razvoj tala i današnje stanje stupnja pogodnosti i plodnosti poljoprivrednog tla, utječu i različite aktivnosti korisnika, vidi Pedološku kartu $\mathrm{KZŽ}$.

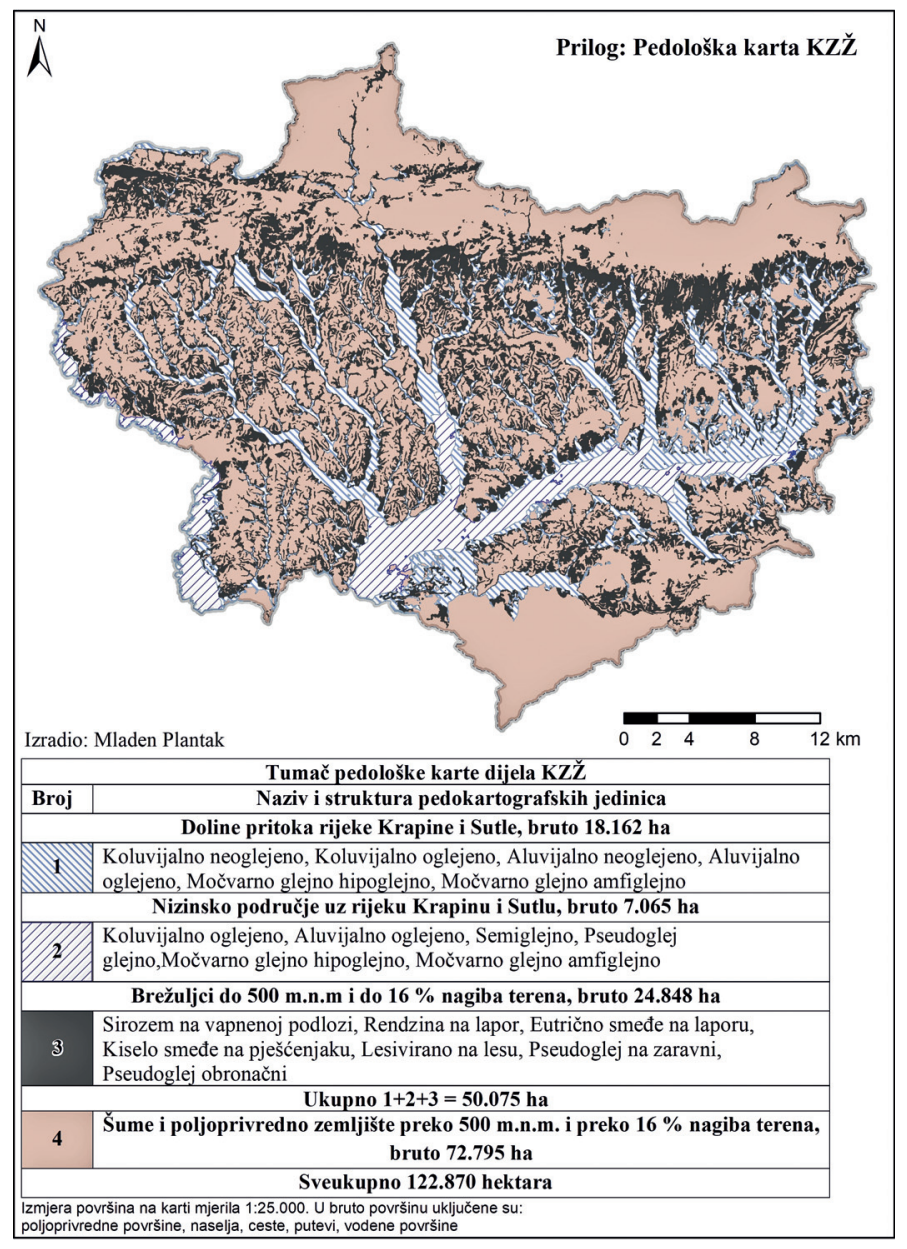


Ž. Vidaček i sur.: Zemljišni i biljno proizvodni uvjeti za natapanje poljoprivrednih kultura u Krapinsko zagorskoj županiji

U dolinama pritoka rijeke Krapine i Sutle bruto 18.162 hektara, dominantni pedološki pokrov čine močvarna, aluvijalna i koluvijalna oglejena i neoglejena tla livada i vlažnih oranica. U nizinskom području uz rijeke Krapinu i Sutlu ukupno bruto 7.065 hektara su koluvijalno oglejeno, aluvijalno oglejeno, pseudoglej glejno, močvarno glejno hipoglejno i močvarno glejno amfiglejno tlo pretežno rasprostranjenih livada i pašnjaka, te semiglejno tlo oranica.

Na brežuljcima i gorju do 500 m.n.m. i do $16 \%$ nagiba terena ukupno bruto 24.848 hektara su pretežno sirozem i rendzina na vapnenoj podlozi, eutrično smeđe na laporu, kiselo smeđe na pješćenjaku, lesivirano na lesu, pseudoglej na zaravni i pseudoglej obronačno tlo oranica, vrtova, voćnjaka, vinograda i travnjaka na brežuljcima.

Specifična značajka močvarnog tla je saturiranost vodom dužeg trajanja, a koluvijalno oglejenog tla kračeg trajanja. Semiglejno tlo je do jednog metra dubine ocjedito, a dublje bude podzemna voda. Koluvijalno neoglejeno tlo je na rubu nizinskog povišenog područja i izvan poplava i visoke podzemne vode.

Sirozem ilovasti ili glinasti je ocjedit i plići od $0,4 \mathrm{~m}$. Rendzina je ocjedita, dolazi na lesu, laporu, laporovitoj glini, pješčenjaku ili na laporovitom vapnencu. Ovisno o podlozi bude plitka do $0.2 \mathrm{~m}$, srednje duboka do $0.4 \mathrm{~m}$ ili duboka preko 0,4 metra. Lesivirano ocjedito duboko tlo se razvija na lesu, ima na površini praškasto ilovastu, a dublje praškasto glinasto ilovastu teksturu. Matični supstrat kiselo smeđeg ilovastog tla je pješčenjak. Eutrično smeđe tlo je na laporu ili laporovitom vapnencu. Pseudoglej s podlogom lesa dolazi na zaravnima brežuljaka i na obroncima gorja. U oba slučaja zajedničko ograničenje su sporo procjedne i/ili stagnirajuće površinske vode unutar dubine tla od jednog metra.

Fizikalne i kemijske značajke navedenih tala su vrlo različite. Nalazimo pjeskovito ilovasta, praškasto ilovasta, praškasto glinasto ilovasta ili glinasta tla. Propusnost ili intenzitet procjeđivanja površinske vode varira od male $0,03 \mathrm{~m} / \mathrm{dan}$ do umjereno brze $3,0 \mathrm{~m} /$ dan. Intenzitet ispiranja onečišćivača iz tla i potencijalno onečišćenje podzemne vode je u korelaciji s propusnosti tla za vodu.

S tim u vezi tri su kategorije osjetljivosti tala na propuštanje onečišćivača: jaka, umjerena i slaba. Jako osjetljiva na propuštanje onečišćivaća su koluvijalno neoglejeno i oglejeno, kiselo smeđe na pješčenjaku, aluvijalno oglejeno i neoglejeno, semiglej i močvarno glejno hipoglejno, umjereno osjetljiva lesivirano tlo, eutrično smeđe na laporu, te slabo osjetljiva rendzina i sirozem na vapnencu, eutrično smeđe glinasto, pseudoglej na zaravni i obronačni, močvarno glejna amfiglejna, (Huddleston 1996., Vidaček i sur. 2009.). 
Ž. Vidaček i sur.: Zemljišni i biljno proizvodni uvjeti za natapanje poljoprivrednih kultura u Krapinsko zagorskoj županiji

Prevladavaju neutralna i alkalična tla. Mjestimično na vapnenoj podlozi sadrže aktivnog vapna preko 40\%. Slabo su humozna s manje od 2-3\% ili dosta humozna 3-5\% organske tvari. Pretežno su slabo opskrbljena fiziološki aktivnim fosforom $\left(\mathrm{P}_{2} \mathrm{O}_{5}\right)$, imajući manje od $10 \mathrm{mg}$ na $100 \mathrm{~g}$ tla. Opskrbljenost fiziološki aktivnim kalijem $\left(\mathrm{K}_{2} \mathrm{O}\right)$ isto tako je raznolika, od slabe opskrbljenosti s $10 \mathrm{mg}$ na $100 \mathrm{~g}$ tla, do dobre opskrbljenosti s preko $20 \mathrm{mg}$ na $100 \mathrm{~g}$ tla, izvor OPK 1972-1983.

\subsection{Procjena sadašnje i potencijalne pogodnosti jedinica tala} poljoprivrednog zemljišta za natapanje

Pedosistematske jedinice poljoprivrednog zemljišta do 500 m.n.m. i nagiba terena do $16 \%$, procjenom su svrstane u redove, klase i podklase pogodnosti ili nepogodnosti za natapanje. prema modificiranoj metodi FAO, (1976. i Vidaček Ž., 1981.). Rezultati procjene su prikazani prema niže opisanim kriterijima, tablice 1 i 2.

Redovi pogodnosti (P) obuhvaćaju tla na kojima natapanje daje prema stupnju pogodnosti dobit i opravdava ulaganja bez štetnih posljedica:

Klase P-1 su pogodna tla bez značajnih ograničenja za natapanje ili s ograničenjima koja neće značajno utjecati na produktivnost, dobit i primjenu natapanja, Klase P-2 su umjereno pogodna tla, s ograničenjima koja umjereno ugrožavaju produktivnost, dobit i primjenu natapanja, Klase P-3 su ograničeno pogodna tla, s ograničenjima koja znatno ugrožavaju produktivnost, dobit i primjenu natapanja.

Redovi nepogodnosti (N) uključuju tla koja su privremeno ili trajno nepogodna za primjenu održivog natapanja: Klase N-1su privremeno nepogodna tla, s ograničenjima koja u postojećem stanju isključuju tehnološki i/ili ekonomski opravdanu primjenu natapanja i Klase N-2 su trajno nepogodna tla, s ograničenjima koja trajno isključuju mogućnost tehnološki i/ili ekonomski opravdanu primjenu natapanja.

Podklase pogodnosti ili nepogodnosti tala, određene su prema vrsti i stupnju ograničenja: dubine tla, dreniranosti ili ocjeditosti, nagibu terenaerodibilnosti ${ }^{10}$, kiselosti, opskrbljenosti biljnim hranjivima, sadržaju humusa u površinskom sloju, viška i/ili manjka vode u tlu.

\footnotetext{
${ }^{10}$ Nagibi 2,5-5\% imaju manji problem s erozijom tla. Nagibi 5-10\% uzrokuju jaču eroziju tla. Ograničen izbor mehanizacije. Poželjno je imati redove okomito na pad terena. Nagibi 10-16\% mogu uzrokovati veći problem s erozijom tla, naročito na većim plantažnim površinama. Zahtijevaju veću pažnju pri izboru mehanizacije. Preporučljivo je izvođenje terasa ili u najmanjoj mjeri treba predvidjeti jarke za kontrolirano površinsko otjecanje vode i/ili obradu tla okomito na pad terena
} 
Ž. Vidaček i sur.: Zemljišni i biljno proizvodni uvjeti za natapanje poljoprivrednih kultura u Krapinsko zagorskoj županiji

Tablica 1. Procjena sadašnje pogodnosti jedinica tala poljoprivrednog zemljišta KZŽ

Table 1 Evaluation of current suitability of soil units of agricultural land for irrigation

\begin{tabular}{|c|c|c|}
\hline $\begin{array}{l}\text { Klasa pogodnosti tla } \\
\text { Soil suitability } \\
\text { clasess }\end{array}$ & $\begin{array}{l}\text { Podklasa pogodnosti tla } \\
\text { (ograničenja-limitations) } \\
\text { Soil suitability subclasess }\end{array}$ & $\begin{array}{l}\text { Pedosistematske jedinice } \\
\text { Soil units }\end{array}$ \\
\hline $\begin{array}{l}\text { P-1 } \\
\text { Pogodno } \\
\text { Suitable }\end{array}$ & hranjiva, humus & $\begin{array}{l}\text { Aluvijalno neoglejeno, } \\
\text { Koluvijalno neoglejeno, } \\
\text { Semiglejno }\end{array}$ \\
\hline $\begin{array}{c}\text { P-2 } \\
\text { Pogodno } \\
\text { Moderately Suitable }\end{array}$ & $\begin{array}{c}\text { hranjiva, humus, srednja dreniranost, } \\
\text { nagib, erozija }\end{array}$ & $\begin{array}{l}\text { Lesivirano na lesu } \\
\text { Eutrično smeđe na laporu }\end{array}$ \\
\hline & hranjiva, humus, nagib, erozija, plitka tla & $\begin{array}{l}\text { Sirozem na vapnenoj podlozi } \\
\text { Renzina na vapnenoj podlozi }\end{array}$ \\
\hline & hranjiva, humus, nagib, erozija, kiselost & Kiselo smeđe na pješčenjaku \\
\hline $\begin{array}{l}\text { Ograničeno pogodno } \\
\text { Moderately Suitable }\end{array}$ & $\begin{array}{l}\text { hranjiva, humus, erozija, dreniranost } \\
\text { slaba, sporo procjedna površinska voda, } \\
\text { vrlo sporo procjedna voda }\end{array}$ & Pseudoglej obronačni \\
\hline & $\begin{array}{l}\text { hranjiva, humus, vrlo slaba dreniranost, } \\
\text { vrlo sporo procjedna površinska voda }\end{array}$ & Pseudoglej na zaravni \\
\hline \multirow{4}{*}{$\begin{array}{c}\text { N-1 } \\
\text { Privremeno } \\
\text { Nepogodno } \\
\text { Temporary } \\
\text { Not Suitable }\end{array}$} & hranjiva, humus, podzemna voda, poplave & $\begin{array}{l}\text { Aluvijalno oglejeno } \\
\text { Koluvijalno oglejeno }\end{array}$ \\
\hline & $\begin{array}{l}\text { hranjiva, dreniranost slaba, } \\
\text { podzemna voda, vrlo sporo procjedna } \\
\text { površinska voda, poplave }\end{array}$ & Pseudoglej glej \\
\hline & hranjiva, podzemna voda, poplave & Močvarno glejno hipoglejno \\
\hline & $\begin{array}{l}\text { hranjiva, dreniranost vrlo slaba, } \\
\text { podzemna voda, površinska voda, } \\
\text { poplave }\end{array}$ & Močvarno glejno amfiglejno \\
\hline $\begin{array}{l}\mathrm{N}-2 \\
\text { Trajno nepogodno } \\
\text { Permanently } \\
\text { Not Suitable }\end{array}$ & \multicolumn{2}{|c|}{$\begin{array}{l}\text { Poljoprivredno zemljište-tlo preko } 500 \text { m.n.m. } \\
\text { i preko } 16 \% \text { nagiba terena }\end{array}$} \\
\hline
\end{tabular}


Ž. Vidaček i sur.: Zemljišni i biljno proizvodni uvjeti za natapanje poljoprivrednih kultura u Krapinsko zagorskoj županiji

Tablica 2. Sadašnja i potencijalna pogodnost i melioracijske mjere jedinica tala poljoprivrednog zemljišta za natapanje u KZŽ

Table 2 Current and potential suitability and amelioration measures of soil units of irrigated agricultural land

\begin{tabular}{|c|c|c|c|c|}
\hline \multicolumn{2}{|r|}{$\begin{array}{l}\text { Pedokartografske jedinice } \\
\text { Pedocartographic unuts }\end{array}$} & \multirow{2}{*}{$\begin{array}{c}\text { Sadašnja } \\
\text { Pogodnost } \\
\text { Current } \\
\text { suitability }\end{array}$} & \multirow{2}{*}{$\begin{array}{l}\text { Melioracijske mjere } \\
\text { Amelioration measures }\end{array}$} & \multirow{2}{*}{$\begin{array}{c}\text { Potencijalna } \\
\text { Pogodnost } \\
\text { Potential } \\
\text { suitability }\end{array}$} \\
\hline $\begin{array}{l}\text { Broj* } \\
\text { No }\end{array}$ & $\begin{array}{l}\text { Naziv i struktura } \\
\text { Name and structure }\end{array}$ & & & \\
\hline \multicolumn{5}{|c|}{$\begin{array}{c}\text { Doline pritoka rijeka Krapine i Sutle, bruto } 18.162 \text { ha** } \\
\text { Valleys of tributaries of rivers Krapina and Sutla }\end{array}$} \\
\hline 1 & $\begin{array}{l}\text { Koluvijalno neoglejeno } \\
\text { Koluvijalno oglejeno } \\
\text { Aluvijalno neoglejeno } \\
\text { Aluvijalno oglejeno } \\
\text { Močvarno glejno hipoglejno } \\
\text { Močvarno glejno amfiglejno }\end{array}$ & $\begin{array}{l}\text { P-2 } \\
\text { N-1 } \\
\text { P-2 } \\
\text { N-1 } \\
\text { N-1 } \\
\text { N-1 }\end{array}$ & $\begin{array}{c}\text { agrotehničke } \\
\text { agro i hidrotehničke } \\
\text { agrotehničke } \\
\text { agro i hidrotehničke } \\
\text { agro i hidrotehničke } \\
\text { agro i hidrotehničke }\end{array}$ & $\begin{array}{l}\text { P-1 } \\
\text { P-1 } \\
\text { P-1 } \\
\text { P-1 } \\
\text { P-1 } \\
\text { P-2 }\end{array}$ \\
\hline \multicolumn{5}{|c|}{$\begin{array}{l}\text { Nizinsko područje uz rijeku Krapinu i Sutlu, bruto } 7.065 \text { ha** } \\
\text { Lowlands of rivers Krapina i Sutla }\end{array}$} \\
\hline 2 & $\begin{array}{c}\text { Koluvijalno oglejeno } \\
\text { Aluvijalno oglejeno } \\
\text { Semiglejno } \\
\text { Pseudoglej glejno } \\
\text { Močvarno glejno hipoglejno } \\
\text { Močvarno glejno amfiglejno }\end{array}$ & $\begin{array}{l}\text { N-1 } \\
\text { N-1 } \\
\text { P-2 } \\
\text { N-1 } \\
\text { N-1 } \\
\text { N-1 }\end{array}$ & $\begin{array}{l}\text { agro i hidrotehničke } \\
\text { agro i hidrotehničke } \\
\text { agrotehničke } \\
\text { agro i hidrotehničke } \\
\text { agro i hidrotehničke } \\
\text { agro i hidrotehničke }\end{array}$ & $\begin{array}{l}\text { P-1 } \\
\text { P-1 } \\
\text { P-1 } \\
\text { P-2 } \\
\text { P-1 } \\
\text { P-2 }\end{array}$ \\
\hline \multicolumn{5}{|c|}{$\begin{array}{c}\text { Brežuljci do } 500 \text { m.n.m i do } 16 \% \text { nagiba terena, bruto } 24.848 \text { ha** } \\
\text { Hills up to } 500 \text { meters above sea level and } 1-16 \% \text { of slope }\end{array}$} \\
\hline 3 & $\begin{array}{l}\text { Sirozem na vapnenoj podlozi } \\
\text { Rendzina na laporu } \\
\text { Eutrično smeđe na laporu } \\
\text { Kiselo smeđe na pješćenjaku } \\
\text { Lesivirano na lesu } \\
\text { Pseudoglej na zaravni } \\
\text { Pseudoglej obronačni }\end{array}$ & $\begin{array}{l}\text { P-3 } \\
\text { P-3 } \\
\text { P-2 } \\
\text { P-3 } \\
\text { P-2 } \\
\text { P-3 } \\
\text { P-3 }\end{array}$ & $\begin{array}{l}\text { agrotehničke } \\
\text { agrotehničke } \\
\text { agrotehničke } \\
\text { agrotehničke } \\
\text { agrotehničke } \\
\text { agro i hidrotehničke } \\
\text { agro i hidrotehničke }\end{array}$ & $\begin{array}{l}\text { P-2 } \\
\text { P-2 } \\
\text { P-1 } \\
\text { P-2 } \\
\text { P-1 } \\
\text { P-2 } \\
\text { P-2 }\end{array}$ \\
\hline \multicolumn{5}{|c|}{ Ukupno $1+2+3=50.075 \mathrm{ha}^{* *}$} \\
\hline 4 & \multicolumn{4}{|c|}{$\begin{array}{l}\text { Šume i poljoprivredno zemljište preko } 500 \text { m.n.m. bruto } 72.795 \text { ha** } \\
\text { Forest and agricultural land over } 500 \text { meters above sea level }\end{array}$} \\
\hline \multicolumn{5}{|c|}{ Sveukupno 122.870 hektara } \\
\hline & $\begin{array}{l}\text { i na karti**Izmjera površina } \\
\text { poljoprivredne površin }\end{array}$ & naselja, ces & putovi, vodene površine & \\
\hline
\end{tabular}


Ž. Vidaček i sur.: Zemljišni i biljno proizvodni uvjeti za natapanje poljoprivrednih kultura u Krapinsko zagorskoj županiji

\section{PREPORUKE}

\subsection{Uređenje poljoprivrednog zemljišta}

U strategiji razvoja Krapinsko zagorske županije 2016. - 2020. godine je navedeno da treba sprečavati degradaciju malih seoskih gospodarstava i depopulaciju ruralnog područja, te poticati povećanje zemljišnog posjeda kao i bolje koristiti postojeće i privoditi svrsi do sada neobrađene i zapuštene poljoprivredne površine.

Navedenu problematiku velikim dijelom otklanjamo primjenom Zakona o komasaciji poljoprivrednog zemljišta odnosno nizom ,administrativnih i tehničkih postupaka kojima se male i usitnjene površine poljoprivrednog zemljišta sjedinjuju u veće i uređenije, uređuju putne i kanalske mreže te sređuju pravni i drugi odnosi na zemljištu. U kontekstu uređenja, riječ je o „vodnim građevinama za melioracije koje se dijele na građevine za osnovnu melioracijsku odvodnju i građevine za detaljnu melioracijsku odvodnju, zatim građevine za natapanje (akumulacijske i druge zahvatne građevine, razvodna mreža i druge građevine pripadajuće tim građevinama) i mješovite melioracijske građevine“ (NN 51/15).

U interesu sadašnje situacije navodimo, da je prije ukidanja Zakona o Arondaciji 1993.godine bilo moguće pripajati manje parcele većem posjedu, bez projektiranja novih putova i hidrotehničkih melioracija. Granice, oblik i veličina novih grupiranih parcela uvjetovane su i ovisile su o pravilnosti postojeće putne i kanalske mreže.

Osim komasacije i arondacije poljoprivrednog zemljišta, privremene mjere okrupnjavanja su zakup i koncesija.

U cilju bolje plodnosti ${ }^{11}$ i produktivnosti tla, agrotehničke melioracije trebaju aluvijalno neoglejeno, koluvijalno neoglejeno, semiglej, lesivirano na lesu, eutrično smeđe na laporu, sirozem na vapnenoj podlozi, rendzina na vapnenoj podlozi i kiselo smeđe tlo. Agrotehničke melioracije u svrhu povećanja plodnosti tla uključuju melioracijsku ${ }^{12}$ obradu melioracijsku gnojidbu $^{13}$ kalcizaciju kiselih tala, humizaciju ili obogaćivanje tla organskim

\footnotetext{
${ }^{11}$ Plodnost tla je sposobnost koja ga čini pogodnim supstratom za uzgoj bilja, imajući dovoljno biljnih hranjiva, vode i zraka (kisika) u svim fazama njihova rasta i razvoja

${ }^{12}$ Melioracijska obrada: duboka obrada, podrivanje, rahljenje tla.

${ }^{13}$ Melioracijska gnojidba: mineralna $i$ organska gnojidba na zalihu do zadovoljavajuće opskrbljenosti tla biljnim hranjivima. Najčešće to budu fosfor i kalij, te obogaćivanje tla organskom tvari-humizacija. Izvori mogu biti različiti: stajski gnoj, razne vrste običnog i industrijskog komposta, uzgoj usjeva za zelenu gnojidbu-sideracija i unošenje žetvenih ostataka-slame i kukuruzovine u tlo.
} 
Ž. Vidaček i sur.: Zemljišni i biljno proizvodni uvjeti za natapanje poljoprivrednih kultura u Krapinsko zagorskoj županiji

gnojivima, protuerozijske mjere (agrotehničke i biološke) i baulaciju. Na ratarskim i povrtlarskim površinama već su vršene agrotehničke melioracije, kao što su podrivanje, zelena gnojidba i kalcizacija po preporuci Hrvatske poljoprivredno šumarske službe.

Primjenu agro i hidrotehničkih melioracija treba za pseudoglej obronačni, pseudoglej na zaravni, aluvijlno oglejeno, koluvijalno oglejeno, močvarno glejno hipoglejno i močvarno glejno amfiglejno tlo, tablici 3.

Tablica 3. Preporuke za agro i/ili hidrotehničke melioracije jedinica tala poljoprivrednog zemljišta

Table 3 Recommendations for amelioration of soil units of agricultural land

\begin{tabular}{|c|c|}
\hline $\begin{array}{l}\text { Podosistematske jedinice } \\
\text { Soil units of aricultural land }\end{array}$ & $\begin{array}{c}\text { Agro i/ili hidrotehničke melioracije } \\
\text { Amelioration measures }\end{array}$ \\
\hline Aluvijalno neoglejeno & melioracijska obrada i gnojidba \\
\hline Koluvijalno neoglejeno & melioracijska obrada i gnojidba \\
\hline Sirozem na vapnenoj podlozi & \multirow{3}{*}{$\begin{array}{l}\text { melioracijska obrada i gnojidba, } \\
\text { zaštita od erozije tla }\end{array}$} \\
\hline Rendzina na laporu & \\
\hline Eutrično smeđe na laporu & \\
\hline Kiselo smeđe na pješćenjaku & $\begin{array}{c}\text { melioracijska obrada i gnojidba, kalcizacija, } \\
\text { zaštita od erozije tla }\end{array}$ \\
\hline Lesivirano na lesu & $\begin{array}{l}\text { melioracijska obrada i gnojidba, podrivanje } \\
\text { podpovršinaskog sloja tla, zaštita od erozije tla }\end{array}$ \\
\hline Koluvijalno oglejeno & \multirow{2}{*}{$\begin{array}{l}\text { melioracijska obrada i gnojidba detaljna odvodnja, } \\
\text { obrana od poplava }\end{array}$} \\
\hline Aluvijalno oglejeno & \\
\hline Semiglejno & melioracijska obrada i gnojidba \\
\hline Pseudoglej glejno & \multirow{2}{*}{$\begin{array}{l}\text { melioracijska obrada i gnojidba, podrivanje } \\
\text { podpovršinaskog sloja tla i/ili plitka cijevna drenaža }\end{array}$} \\
\hline Pseudoglej na zaravni & \\
\hline Pseudoglej obronačni & $\begin{array}{c}\text { melioracijska obrada i gnojidba, } \\
\text { podrivanje podpovršinaskog sloja tla }\end{array}$ \\
\hline Močvarno glejno hipoglejno & $\begin{array}{l}\text { detaljna odvodnja, cijevna drenaža, } \\
\text { melioracijska obrada i gnojidba }\end{array}$ \\
\hline Močvarno glejno amfiglejno & $\begin{array}{l}\text { detaljna odvodnja, cijevna drenaža, melioracijska } \\
\text { obrada i gnojidba, podrivanje ili krtična drenaža }\end{array}$ \\
\hline
\end{tabular}


Ž. Vidaček i sur.: Zemljišni i biljno proizvodni uvjeti za natapanje poljoprivrednih kultura u Krapinsko zagorskoj županiji

\subsection{Natapanje ratarskih i povrtnih kultura na oranicama}

\subsubsection{Izbor kultura}

Potencijalna područja prioriteta za natapanje ratarskih i povrtnih kultura i cvijeća su na uređenom poljoprivrednom zemljištu u dolinama pritoka Krapine i Sutle, ukupno bruto 25.227 hektara. Izbor ratarskih kultura čine: kukuruz, krumpir, strne žitarice, uljne tikve, industrijska konoplja, lan, proso, pir, stočni grašak, lucerna, facelija,djeteline, DTS-i i trave. U proizvodnji povrća to su: rajčica, krastavci, salata, cvjetača, kupus, kelj, tikvenjače, grah, grašak, paprika, mahune, bob, cikla, mrkva, patlidžan, luk, feferoni, batat i češnjak.

Za izbor kultura, u prvom redu su kompetentni i odgovorni specijalizirani ratari, povrćari, voćari, vinogradari, cvjećari, agrarni ekonomisti i poljoprivredni stručnjaci Hrvatske poljoprivredno-šumarske savjetodavne službe.

\subsubsection{Varijante intenzivnog uzgoja povrtnih i ratarskih kultura}

$\mathrm{Na}$ oranicama $\mathrm{s}$ natapanjem se preporuča prostorna i vremenska izmjena ratarskih i povrtnih usjeva po načelu intenziviranog plodoreda i uzgoja naknadnih usjeva-,,druge žetve“. Koristi se veći broj kultura u jednoj rotaciji ${ }^{14}$ na račun ugara, koji smanjuje učinkovitost korištenja zemljišta. U rotaciji treba voditi računa da se kukuruz za zrno uzgaja na površinama gdje su bile mahunarke za zrno, krumpir, povrće, šećerna repa, kukuruz i lucerna. Kukuruz za silažu se uzgaja na poljima na kojima su predkulture bile ozima pšenica i raž. Mahunarke dolaze nakon kukuruza, šećerne repe, povrća, krumpira i ostalih okopavina. Šećerna repa se uzgaja iza leguminoza za zrno, ozime pšenice, kukuruza, soje, krumpira i povrća. Lucerna u proljetnoj sjetvi se uzgaja poslije okopavina i često se sije s prosom i ječmom. Krumpir se u proljeće sadi nakon korjenastog bilja. Povrtne kulture gaje se poslije kukuruza, lucerne i šećerne repe. Neke se povrtne kulture smiju sijati ili saditi na istoj površini tek nakon 3 do 5 godina (grah, cikla, krastavci-3 godine, paprika, patliđan, tikvice-4 godine, a luk i češnjak 5 godina). Rajčica dosta dobro podnosi samu sebe, nisu dobre predkulture paprika i krumpir, a nakon nje obično se siju ili sade kulture kratke vegetacije (salata, rotkvica, mladi luk) kako bi se na proljeće mogla ponovo saditi (ponoviti sadnja) uz prethodno provođenje dezinfekcije tla. Naknadni povrtni usjevi slijede poslije žetve ozime pšenice, graška i ranog povrća. Nakon uzgoja krastavaca (većinom kornišoni) na armaturi, sljedeće kulture mogu biti mahune ili grah.

\footnotetext{
${ }^{14}$ Rotacija ili ophodnja prostorna je izmjena usjeva po plodorednim poljima, a ostvaruje se podjelom oraničnog zemljišta na dva, tri ili više plodorednih polja.
} 
Ž. Vidaček i sur.: Zemljišni i biljno proizvodni uvjeti za natapanje poljoprivrednih kultura u Krapinsko zagorskoj županiji

$\mathrm{Na}$ okrupnjenom i melioriranom poljoprivrednom zemljištu očekujemo veće proizvodne parcele s raznim varijantama intenzivnog uzgoja povrtnih i ratarskih kultura, kao na primjer povrtlarska proizvodnja na 3 hektara i ratarska proizvodnja na 5 hektara, tablica 4, Pospišil M. $2018^{15}$.

Ima i drugih varijanti, kao na primjer ratarsko-povrtlarska proizvodnja na 3 ha, ratarska proizvodnja + proizvodnja mlijeka i teladi na 10 ha, ratarska proizvodnja + tov junadi i junica na 10 hektara, (Vidaček Ž., 1998.).

Tablica 4. Varijante intenzivne povrtne i ratarske proizvodnje, (Pospišil M., 2018.)

Table 4 Variants of intensive vegetable and crop production, (Pospišil M., 2018)

\begin{tabular}{|l|c|c|l|c|c|}
\hline \multicolumn{3}{|c|}{$\begin{array}{c}\text { Povrtna proizvodnja, 3 hektara } \\
\text { Vegetable crops production, 3 hectares }\end{array}$} & \multicolumn{3}{c|}{$\begin{array}{c}\text { Ratarska proizvodnja, 5 hektara } \\
\text { Crop production, 5 hectares }\end{array}$} \\
\hline \multicolumn{1}{|c|}{ Kulture-Culture } & ha & $\begin{array}{l}\text { Sjetva-Berba } \\
\text { Sowing-Harvest }\end{array}$ & \multicolumn{1}{|c|}{ Kulture-Culture } & ha & $\begin{array}{c}\text { Sjetva-Berba } \\
\text { Sowing-Harvest }\end{array}$ \\
\hline $\begin{array}{l}\text { Mrkva } \\
\text { Carrot }\end{array}$ & 0,5 & $1.04 .-20.10$. & $\begin{array}{l}\text { Ozimi ječam } \\
\text { Winter barley }\end{array}$ & 0,83 & $10.10 .-01.07$ \\
\hline $\begin{array}{l}\text { Tikvica } \\
\text { Zucchini }\end{array}$ & 0,5 & $5.05 .-15.07$. & $\begin{array}{l}\text { Heljda, naknadni } \\
\text { Buckwheat, } \\
\text { additional }\end{array}$ & 0,83 & 5.07 .30 .10$. \\
\hline $\begin{array}{l}\text { Češnjak } \\
\text { Garlic }\end{array}$ & 0,5 & $15.10 .-10.07$. & $\begin{array}{l}\text { Uljna buča } \\
\text { Oil pumpkins }\end{array}$ & 0,83 & $5.05 .-30.09$. \\
\hline $\begin{array}{l}\text { Cikla, naknadni } \\
\text { Beetroot, additional }\end{array}$ & 0,5 & $15.07 .-30.10$. & $\begin{array}{l}\text { Ozima pšenica } \\
\text { Winter wheat }\end{array}$ & 0,83 & $20.10 .-10.07$. \\
\hline $\begin{array}{l}\text { Peršin } \\
\text { Parsley }\end{array}$ & 0,5 & $1.04 .-20.10$. & $\begin{array}{l}\text { Facelija, naknadni } \\
\text { Phacelia, additional }\end{array}$ & 0,83 & $15.07 .-30.10$. \\
\hline $\begin{array}{l}\text { Krastavac } \\
\text { Cucumber }\end{array}$ & 0,5 & $20.05 .-20.07$. & $\begin{array}{l}\text { Batat } \\
\text { Sweet potato }\end{array}$ & 0,83 & $20.05 .-20.09$. \\
\hline $\begin{array}{l}\text { Luk } \\
\text { Onion }\end{array}$ & 0,5 & $1.04 .-15.07$. & $\begin{array}{l}\text { Pir } \\
\text { Spelt }\end{array}$ & 0,83 & $15.10 .-10.07$. \\
\hline $\begin{array}{l}\text { Grah mahunar, } \\
\text { naknadni } \\
\text { Green beans, } \\
\text { additional }\end{array}$ & 0,5 & $20.07 .-30.09$. & $\begin{array}{l}\text { Krumpir } \\
\text { Potato }\end{array}$ & $\begin{array}{l}\text { *Indeks korištenja zemljišta- } \\
\text { Land use index: } 1,32\end{array}$ \\
\hline $\begin{array}{l}\text { *Indeks korištenja zemljišta- } \\
\text { Land use index: } 1,33\end{array}$ & 0,83 & $10.04 .-10.09$. \\
\hline *Indeks bez naknadnog usjeva je 1,0. Kod dvije žetve na 32 ili 33\% površine je 1,33 i 1,32. \\
\hline
\end{tabular}

${ }^{15}$ Milan Pospišil je redoviti profesor u Zavodu za specijalnu proizvodnju bilja Agronomskog fakulteta, Zagreb 
Ž. Vidaček i sur.: Zemljišni i biljno proizvodni uvjeti za natapanje poljoprivrednih kultura u Krapinsko zagorskoj županiji

6.3. Natapanje voća, vinove loze i interventna natapanja

Suša ostavlja ozbiljne posljedice na visinu prinosa i kvalitetu voća, tako da bi se u proizvodnji za tržište, trebalo natapati jagode, aroniju, kupine, maline, jabuke, kruške i breskve. Prioritetno područje za uzgoj voća i povrća su brežuljci do 500 m.n.m., nagiba do 16\% i ukupne bruto površine 7.065 hektara.

U vrijeme žestokih suša, natapanje koristi u ekstenzivnom voćnjaku okućnice, za ozime i jare kulture u fazi nicanja i/ili klijanja. Natapanje vinove loze može se koristiti pri sadnji ili i u punom rodu samo za vinske kultivar posebnih namjena. Po potrebi se može primijeniti natapanje u matičnjacima američkih vrsta i njihovih križanaca - podloge za vinovu lozu.

Posebnim uređajima za kišu, koristi se prilično pouzdano natapanjeorošavanje u voćnjacima za zaštitu od mraza amplitude $-1^{0}$ do $-7^{0} \mathrm{C}$ i kraćeg trajanja-nekoliko sati.

Za vrućih ljeta s visokom temperaturom i niskom relativnom vlagom zraka, koriste se osvježavajuća natapanja. Broj intervencija ovisi o intenzitetu i trajanju vrućine, vrsti i razvojnoj fazi usjeva i sadržaju vode u tlu. Neto obroci natapanja budu 2-3 mm ili 20-30 m³/ha, (Vidaček Ž.,1998.).

\section{ZAKLJUČAK}

Rezultati procjene pogodnosti pedosistematskih jedinica poljoprivrednog zemljišta za natapanje pokazuju, da su tla županije u sadašnjem stanju ograničene pogodnosti za intenzivnije korištenje i natapanje. Poljoprivredna tla na brežuljcima bruto 24.848 ha su plitka i srednje duboka, erodibilna, mjestimično kisela na pješčenjaku, češće bazična na vapnenoj podlozi, slabo opskrbljena biljnim hranjivima i humusom. U dolinama i nizinskom području uz Krapinu i Sutlu bruto 25.227 ha, osim manje plodnosti tla budu poplave i mraz. Uvažavajući utvrđena ograničenja za intenzivnije korištenje poljoprivrednog zemljišta i sve češće godišnje i/ili sezonske pojave suše, predložene su agrotehničke i/ili hidrotehničke melioracije s natapanjem, tablice 1 - 3 .

Osnovna obilježja poljoprivrednih gospodarstava županije su usitnjenost, rascjepkanost i veličina posjeda. Najveće štete od suše budu na ratarskim i krmnim usjevima, te na povrću i cvijeću. $\mathrm{Na}$ manjim poljoprivrednim gospodarstvima su veći troškovi proizvodnje, manji dohodak i nesigurna 
Ž. Vidaček i sur.: Zemljišni i biljno proizvodni uvjeti za natapanje poljoprivrednih kultura u Krapinsko zagorskoj županiji

konkurentnost na tržištu. Za ekonomičnu i rentabilnu biljnu proizvodnju uz natapanje, treba koristiti veća gospodarstva, dohodovne i visokoproduktivne kulture i suvremenu tehnologiju. S time u vezi, predlažemo komasaciju, arondaciju, zakup, koncesiju poljoprivrednog zemljišta, primjenu intenzivnih načina gospodarenja $\mathrm{s}$ dvije žetve i združeni nastup na domaćem i stranom tržištu.

Osim navedenog, moramo se pozabaviti problemima izvora vode za natapanje, novih tehnologija, digitalizacije poljoprivrede, skladištenja, sabirnih centara, silosa, politike otkupa, dorade i prerade, udrugama, klasterima, zadrugama, radnoj snazi u poljoprivredi, te interesima i sposobnošću poljoprivrednih proizvođača.

\section{LITERATURA:}

1. Huddleston, J. H. (1996.): How soil properties affect groundwater vulnerability to pesticide contamination, Oregon State University Extension Soil Science, Corvallis

2. Lešić, R i sur. (2002.): Povrćarstvo, Zrinski, Čakovec

3. Romić, D. i Marušić, J. (2005.): Nacionalni projekt navodnjavanja i gospodarenja poljoprivrednim zemljištem i vodama u republici Hrvatskoj, separat iz Građevnog godišnjaka '05/'06, Zagreb

4. Vidaček, Ž. i Bensa, Aleksandra (2008.): Suša u prostoru i vremenu Hrvatske, Gazophylacium, god.XIII., br. 3-4 , str.125-133, Zagreb

5. Vidaček, Ž. (1981.): Procjena proizvodnog prostora i prikladnosti tla za natapanje u Istočnoj Slavoniji i Baranji, disretacija, Fakultet Poljoprivrednih znanosti Sveučilišta u Zagrebu

6. Vidaček Ž., (1979.): Osnovni principi procjene zemljišta, Zemljište i biljka, vol.28, No 1-2, 51-85, Beograd

7. Vidaček, Ž. (1998.): Gospodarenje melioracijskim sustavima odvodnje i natapanja, sveučilišni udžbenik, Agronomski fakultet Zagreb i Hrvatsko društvo za odvodnju i natapanje, Zagreb

8. Vidaček, Ž. i sur. (2009.): Studija osjetljivosti tla i ranjivosti podzemnih voda na onečišćenje s površine poljoprivrednog zemljišta, Zavod za pedologiju, Agronomski fakultet Sveučilišta u Zagrebu

xxx Agencija za plaćanja u poljoprivredi, ribarstvu i ruralnom razvoju (2012.): Vodič kroz višestruku sukladnost, Zagreb 
Ž. Vidaček i sur.: Zemljišni i biljno proizvodni uvjeti za natapanje poljoprivrednih kultura u Krapinsko zagorskoj županiji

xxx Agencija za plaćanja u poljoprivredi, ribarstvu i ruralnom razvoju (2016.):

Ustupljeni podaci u tablici 1 i 2

xxx Arhiva Hrvatskih voda (2016.): Ustupljeni podaci na temelju zahtjeva

xxx FAO, (1976.): A Framework for Land Evaluation, Soils Bulletin No.32, Rome

xxx Grupa autora, (1972 - 1983): Osnovna pedološka karta Hrvatske(OPK ), mjerila 1:50000, listovi Ptuj 3, Rogatec 4, Samobor 2 i Zagreb 1, Projektni savjet za izradu osnovne pedološke karte Hrvatske, Zagreb

xxx Krapinsko-zagorska županija (2015.): Nacrt Strategije razvoja Krapinskozagorske županije Strategija razvoja Krapinsko-zagorske županije 2016. - 2020. Zagorska razvojna agencija d.o.o.

xxx Krapinsko-zagorska županija (2012.): Prostorni plan županije, Upravni odjel za prostorno planiranje, zaštitu okoliša i graditeljstvo, Zavod za prostorno uređenje

xxx Program ruralnog razvoja Republike Hrvatske za razdoblje 2014. - 2020. Ministarstvo poljoprivrede, 2015

xxx Zakon o komasaciji poljoprivrednog zemljišta, NN. 51/15

Adrese autora - Author's addresses:

Prof.dr.sc. Željko Vidaček, dipl.ing.agr. pedolog u mirovini, Marija Bistrica

Dragica Tresk Penezić, dipl.ing.agr., Hrvatska poljoprivredno-šumarska savjetodavna služba, Podružnica Krapinsko-zagorske županije, Donja Stubica

Mladen Plantak, mag.geogr., Elektroprojekt d.d.

Alexsandera von Humboldta 4, Zagreb
Primljeno - Received

25.06.2018. 
Ž. Vidaček i sur.: Zemljišni i biljno proizvodni uvjeti za natapanje poljoprivrednih kultura u Krapinsko zagorskoj županiji 